\title{
SEBARAN DAN TINGKAT SERANGAN HAMA PENGGEREK BUAH KAKAO (Conopomorpha cramerella Snellen) PADA LAHAN BUKAAN BARU DI KABUPATEN DHARMASRAYA
}

\author{
The Distribution and Level of Cocoa Pod Borer (Conopomorpha cramerella Snellen) Attack in \\ the New Opening Land in Dharmasraya Regency \\ Yuli Suherlina ${ }^{1}$, Yaherwandi ${ }^{2}$, Siska Efendi ${ }^{1 *}$ \\ ${ }^{1}$ Program Studi Agroekoteknologi, Jurusan Budidaya Perkebunan, Fakultas Pertanian, \\ Kampus III Universitas Andalas Dharmasraya \\ Jl. Lintas Sumatera Km 4 Pulau Punjung, Dharmasraya (27612), Indonesia \\ ${ }^{2}$ Program Studi Proteksi Tanaman, Fakultas Pertanian, Universitas Andalas, \\ Limau Manis, Padang (25163), Indonesia \\ *Email : siskaefendi@agr.unand.ac.id
}

Diterima 3 Februari 2020/Disetujui 20 April 2020

\begin{abstract}
ABSTRAK
Penelitian ini bertujuan untuk mengetahui sebaran dan tingkat serangan penggerek buah kakao di Kecamatan Sitiung, Kabupaten Dharmasraya. Penelitian ini dilaksanakan di empat lokasi, yaitu Sitiung, Siguntur, Gunung Medan dan Sungai Duo. Di setiap lokasi, dilakukan lima kali pengambilan sampel dengan selang waktu 1 minggu. Penelitian berjalan selama bulan JuliSeptember 2018, menggunakan metode purposive sampling atau pengambilan sampel dengan tujuan tertentu. Sampel diambil pada pertanaman kakao produktif berumur lebih dari empat tahun. Hasil penelitian menunjukkan serangan penggerek buah kakao tertinggi terjadi di Siguntur, dengan tanaman terserang $65,80 \%$, buah terserang 18,29\%, intensitas serangan $76 \%$ dan kehilangan hasil $7,61 \%$. Kejadian serangan penggerek buah kakao terendah dijumpai di Gunung Medan dengan tanaman terserang $34,11 \%$, buah terserang $4,64 \%$, intensitas serangan $15,91 \%$ dan kehilangan hasil $1,57 \%$. Serangan penggerek tertinggi pada buah kakao yang terletak pada cabang sekunder.
\end{abstract}

Kata kunci: tingkat serangan, penggerek buah kakao

\section{ABSTRACT}

This study aimed to determine the distribution and level of cocoa pod borer attacks in Kecamatan Sitiung, Kabupaten Dharmasraya. This research was conducted in four locations, namely Sitiung, Siguntur, Gunung Medan and Sungai Duo. At each location, five samples were taken with an interval of 1 week. The study was conducted during July-September 2018, using the method of purposive sampling or sampling with a specific purpose. Samples were taken at productive cocoa plantations over four years old. The results showed the highest cocoa pod borer occurred in Siguntur, with $65,80 \%$ of plants, $18,29 \%$ of fruits, $76 \%$ of intensity and $7,61 \%$ yield loss. The lowest cocoa pod borer attack was found in Medan with 34,11\% plants affected, 4,64\% fruits attacked, $15,91 \%$ intensity of attacks and $1,57 \%$ yield losses. The highest borers attack on cacao fruit which is located on secondary branches.

Keywords: attacking intensity, cacao pod borer 


\section{PENDAHULUAN}

Kakao (Theobroma cacao L.) merupakan komoditas perkebunan penting untuk menunjang perekonomian Indonesia. Buah kakao digunakan sebagai bahan baku berbagai produk makanan, obat dan kosmetik. Hal ini membuat kakao menjadi penunjang ekonomi keluarga petani dan sumber penghasil devisa negara. Di Indonesia kakao diusahakan oleh beberapa pihak terutama perkebunan rakyat, swasta dan negara. Sebagian besar perkebunan kakao di Indonesia berbentuk perkebunan rakyat. Berdasarkan data Direktorat Jenderal Perkebunan (2017), luas perkebunan rakyat pada tahun 2013-2017 berturut-turut sebesar 1.660.767 Ha; $1.686 .178 \mathrm{Ha} ; 1.667 .337 \mathrm{Ha}$; 1.659.598 Ha; dan 1.649.827 Ha.

\section{Data International Cocoa} Organization (ICCO) menunjukkan bahwa Pantai Gading merupakan produsen kakao terbesar di dunia, Ghana menempati posisi kedua, Indonesia posisi ketiga, Nigeria posisi keempat dan Kamerun urutan kelima. Indonesia menyumbang $15 \%$ kebutuhan kakao dunia, sedangkan sebanyak $85 \%$ kebutuhan kakao dunia masih dikuasi oleh negara lain seperti Pantai Gading (39\%), Ghana (22\%), Nigeria (11\%), dan Kamerun (6\%) dan sisanya $7 \%$ berasal dari negara lainnya (Kiranta dan Meydianawathi 2014).

Hal yang menyebabkan rendahnya produksi dan mutu kakao Indonesia adalah pengembangan produk hilir yang masih terbatas dan kualitas hasil perkebunan yang masih rendah, antara lain akibat serangan organisme pengganggu tanaman. Serangan hama penggerek buah kakao (PBK) menyebabkan cita rasa biji kakao Indonesia lemah, kadar kotoran tinggi, serta banyak terkontaminasi bakteri. Kendala yang menyebabkan buruknya kualitas kakao tersebut masih belum sepenuhnya dapat diatasi, mulai dari tahap produksi, pascapanen, maupun industri hilir (Djalil 2008). Kehilangan hasil akibat hama dan penyakit rata-rata mencapai $30 \%$ per tahun (Karmawati 2010), dan biaya pengendaliannya menghabiskan sekitar $40 \%$ dari biaya produksi kakao (Sulistyowati 2003).

Menurut Priyatno (2015), hama yang menyerang tanaman kakao antara lain kepik penghisap buah (Helopeltis spp.), penggerek batang coklat (Zeuzera coffeae), kutu putih (Planococus citri), ulat kilan/ulat jengkal (Hyposidra talaca) dan ulat kantong (Clania sp., Mahasena sp.). Di antara hama tersebut, penggerek buah kakao (PBK) menimbulkan kerusakan tertinggi (Siswanto dan Karmawati 2012).

Secara morfologi tidak ada perbedaan antara buah kakao yang terserang PBK dengan yang sehat. Gejala PBK baru tampak dari luar ketika buah matang. Warna kulit buah kakao yang terserang agak jingga atau pucat keputihan, bobot buah meningkat dan bila diguncang antara biji dengan dinding buah tidak terdengar suara benturan. Kondisi ini disebabkan karena terbentuknya lendir dan kotoran pada daging buah dan kerusakan biji. Hama PBK menghasilkan enzim heksokinase, malat dehidrogenase, esterase fluoresen dan enzim malat enzim polimorfisme yang merusak dinding buah (Tan et al. 1988).

Akibat serangan PBK biji kakao menjadi keriput dan kulit biji berwarna gelap. Hal ini mengakibatkan turunnya bobot dan mutu biji serta meningkatnya biaya panen, akibat penambahan waktu dan tenaga kerja untuk memisahkan biji sehat dari biji yang rusak. Di Indonesia serangan PBK terjadi di berbagai sentra produksi yakni Sulawesi Utara, Maluku Utara, Jawa, Sumatera Utara, dan Sumatera Barat. Tingkat serangan PBK di Sumatera Barat dan Sulawesi Tengah menyebabkan kehilangan hasil masingmasing sebesar $75 \%$ dan $80 \%$ (Wiryadiputra 
et al. 1994). Pengendalian PBK sulit dilakukan karena larva menyerang buah sejak telur menetas, kemudian masuk ke dalam buah dan berkembang disana (Wardojo 1980; Depparaba 2002).

Di Sumatera Barat, kabupaten yang sedang mengembangkan kakao adalah Dharmasraya. Di kabupaten ini pada tahun 2016, terdapat 2.108,88 ha pertanaman kakao yang tersebar di 11 kecamatan, dengan Sitiung sebagai sentra utama kakao. Di kecamatan Sitiung terdapat empat lokasi pertanaman kakao, yaitu Sungai Duo, Sitiung, Siguntur dan Gunung Medan dengan total luas lahan tahun 2016311,22 ha. Ratarata produktivitas kakao tahun 2016 di Kabupaten Dharmasraya 549,94 kg/ha. (BPS 2015). Produksi kakao di kabupaten ini tergolong rendah, salah satu penyebabnya adalah serangan PBK, dengan tingkat serangan berbeda antar nagari.

Secara umum informasi mengenai hama dan penyakit pada tanaman kakao di Kabupaten Dharmasraya masih terbatas, termasuk PBK. Dalam usaha menyusun strategi pengendalian hama PBK diperlukan informasi hama, sebaran dan tingkat serangannya di lapangan. Penelitian ini bertujuan untuk mempelajari sebaran populasi dan tingkat serangan hama penggerek buah kakao di Kecamatan Sitiung.

\section{METODE PENELITIAN}

\section{Keadaan Umum}

Penelitian ini dilakukan di Nagari Siguntur, Sitiung, Gunung Medan dan Sungai Duo, Kecamatan Sitiung, Kabupaten Dharmasraya. Letak geografis Kecamatan Sitiung $0^{0} 55^{\prime} 01^{\prime \prime}-1^{0} 05^{\prime} 43^{\prime \prime} \quad$ LS dan $101^{0} 31^{\prime} 59^{\prime \prime}-101^{0} 43$ '30"BT. Luas daerah $124,57 \mathrm{~km}^{2}$, dan ketinggian 105-125 m dpl, suhu harian $6^{0} \mathrm{C}^{-} 32^{0} \mathrm{C}$ dan curah hujan ratarata $256,36 \mathrm{~mm} /$ bulan. Penentuan lokasi dilakukan secara purposive sampling, yaitu dengan mempertimbangkan luas lahan, serangan hama, dan tanaman yang telah berproduksi. Berdasarkan pertimbangan tersebut, lokasi penelitian yang dipilih yaitu Kecamatan Sitiung, yang selanjutnya dipilih sebanyak 4 nagari. Pada masing-masing lokasi, dibuat 1 petak kebun kakao dengan luas $\pm 0,25$ ha dan pada masing-masing kebun dipilih tanaman sampel secara acak sebanyak $10 \%$ dari tanaman yang ada atau sekitar 25 pohon. Sampel yang sudah ditentukan selanjutnya diberi tanda dan nomor menggunakan label.

Pengamatan yang dilakukan meliputi persentase buah terserang, letak buah terserang, persentase tanaman terserang dan intensitas serangan. Pengamatan dilakukan setiap minggu dengan 5 kali pengamatan.

Pengamatan kondisi tanaman dilakukan pada masing-masing lahan penelitian yang terdiri atas varietas kakao, jarak tanam, umur tanaman dan kegiatan budidaya seperti pemangkasan, sanitasi, pemupukan serta pengendalian hama penyakit. Data diperoleh dengan cara melihat langsung ke lapangan (observasi) dan mewawancarai pemilik kebun untuk mendapatkan informasi tentang pertanaman kakao pada lahan tersebut.

\section{Persentase tanaman dan buah terserang}

Persentase tanaman dan buah terserang adalah nisbah antara tanaman atau buah yang terserang PBK dengan keseluruhan tanaman. Tujuan menghitung presentase tanaman dan buah terserang adalah untuk mengetahui informasi penyebaran PBK pada lahan. Persentase tanaman dan buah terserang PBK dihitung menggunakan rumus sebagai berikut:

Keterangan :

$$
P=\frac{a}{b} x 100 \%
$$

$\mathrm{P}=$ Persentase tanaman atau buah terserang

$\mathrm{a}=$ Jumlah tanaman yang terserang PBK

$\mathrm{b}=$ Jumlah keseluruhan tanaman yang diamati 
Tabel 1 Kategori tingkat kerusakan buah akibat serangan PBK

\begin{tabular}{|c|l|c|}
\hline $\begin{array}{c}\text { Kategori tingkat } \\
\text { kerusakan buah }\end{array}$ & \multicolumn{1}{|c|}{ Kriteria biji lengket } & $\begin{array}{c}\text { Nilai } \\
\text { pembobot }\end{array}$ \\
\hline Bebas & $\begin{array}{l}\text { Semua biji kakao mudah dikeluarkan dari kulit } \\
\text { buah, antar biji tidak lengket }\end{array}$ & 0 \\
\hline Ringan & $\begin{array}{l}\text { Semua biji dapat dikeluarkan dari kulit, biji tidak } \\
\text { terlalu lengket (biji lengket <10\%). }\end{array}$ & 1 \\
\hline Sedang & $\begin{array}{l}\text { Biji saling lengket tetapi masih dapat dikeluarkan } \\
\text { dari kulit buah (biji lengket 10-50\%). }\end{array}$ & 3 \\
\hline Berat & $\begin{array}{l}\text { Biji saling lengket dan tidak dapat dikeluarkan dari } \\
\text { kulit buah (biji lengket }>50 \%)\end{array}$ & 9 \\
\hline
\end{tabular}

Sumber: Sulistyowati et al. (2007)

\section{Pengamatan letak buah terserang}

Letak buah terserang diamati pada batang utama, cabang primer dan cabang sekunder. Tujuannya untuk mengetahui peletakan telur pada buah, batang dan cabang tanaman kakao.

\section{Pengamatan intensitas serangan PBK} Intensitas serangan PBK dilaksanakan dengan tahapan: (1) mengambil 50 buah secara acak, (2) membelah buah dan mengeluarkan bijinya, (3) mengamati semua biji yang ada dalam buah. Biji-biji yang lengket pada kulit buah maupun lengket satu sama lain dikategorikan terserang. Pengukuran intensitas serangan PBK didasarkan atas banyaknya biji lengket pada setiap buah yang diamati, yang dibedakan menjadi empat kategori yaitu sehat, ringan (R), sedang (S), dan berat (B). Penghitungan intensitas kerusakan menggunakan rumus:

$$
I=\frac{\sum\left(N_{i} x S_{i}\right)}{N x S} \times 100 \%
$$

Keterangan :

I = intensitas serangan

$\mathrm{Ni}=$ jumlah buah terserang pada skala serangan tertentu

$\mathrm{Si}=$ skala serangan tertentu

$\mathrm{N}=$ jumlah seluruh buah yang diamati

$\mathrm{S}=$ nilai skala tertinggi
Pengamatan persentase kehilangan hasil

Persentase kehilangan hasil pada kakao adalah perbandingan antara jumlah biji kakao yang tidak dapat dipanen dengan jumlah biji total, dinyatakan dalam persen. Persentase kehilangan hasil dihitung berdasarkan rumus intensitas serangan yang dikemukakan oleh Sulistyowati (1997).

$$
Y=-0,0210+0,1005 X
$$

Keterangan :

$\mathrm{Y}=$ kehilangan hasil

$\mathrm{X}=$ nilai intensitas serangan $\mathrm{PBK}$

\section{HASIL DAN PEMBAHASAN}

\section{Kondisi umum tanaman kakao}

Varietas kakao yang ditanam petani di Kecamatan Sitiung yakni Criollo, Forastero dan Trinitario. Bibit yang digunakan hasil dari pembibitan sendiri. Budidaya kakao di Nagari Gunung Medan dilakukan secara intensif, seperti dilakukan pemangkasan pohon dan pengelolaan kebersihan lahan. Sementara pada tiga lokasi lain, kebun kakao tidak dipelihara secara intensif. Perbedaan pemeliharaan antar lokasi diduga mendukung berkembangnya PBK. Pertumbuhan hama cepat pada lahan yang tidak bersih dan pemangkasan tidak intensif menyebabkan tajuk antar tanaman menjadi 
tumpang tindih, sehingga kondisi iklim mikro tanaman menjadi lembab.

Petani di Nagari Siguntur, Sitiung dan Sungai Duo memiliki kebiasaan membuang sisa panen di lahan. Pada saat pengamatan terlihat tumpukan kulit kakao sisa panen yang berserakan di areal lahan serta serasah daun dibiarkan berserakan pada permukaan tanah (Gambar 1). Deskripsi kondisi pertanaman kakao pada Kecamatan Sitiung terdapat pada Tabel 2.

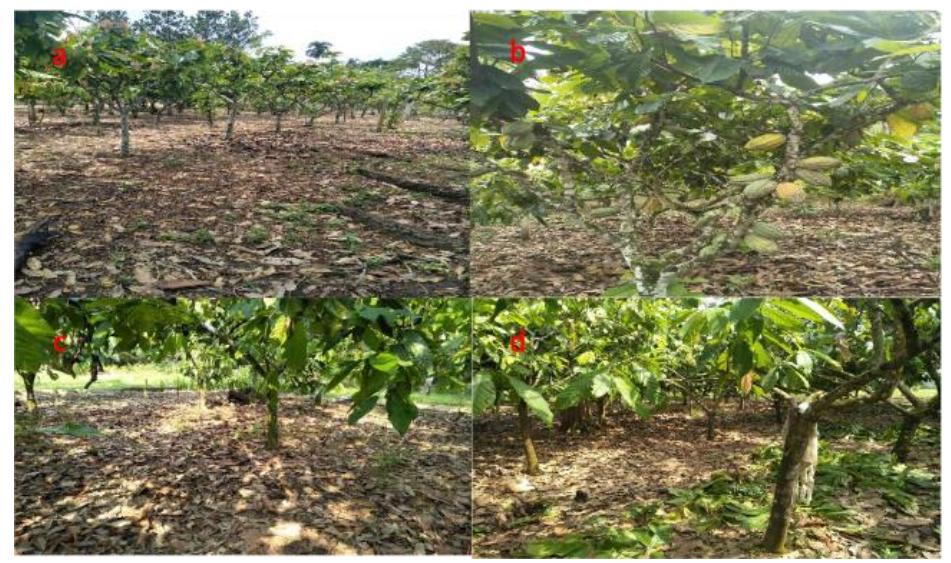

Gambar 1 Kondisi kebun kakao. a) Nagari Gunung Medan, b) Sitiung, c) Sungai Duo dan d) Siguntur

\section{Persentase tanaman terserang}

Berdasarkan hasil pengamatan

diketahui terdapat perbedaan persentase serangan PBK antar lokasi penelitian. Serangan PBK paling tinggi dijumpai di Nagari Siguntur yakni $59,93 \%$ dan persentase terendah di Nagari Gunung Medan yakni 41,54\%. Yulita (2014), melaporkan bahwa tanaman yang diserang PBK di Kabupaten Pasaman Barat pada Kecamatan Ranah Batahan, Koto Balingka dan Sungai Beremas berturut-turut sebesar $66,66 \%, 76,66 \%$ dan 83,33\%. Hal yang sama juga dilaporkan Siska (2015) bahwa tanaman kakao yang terserang PBK di Kabupaten Agam pada Kecamatan IV Angkat, Baso dan Candung berturut-turut adalah $83 \%, 65,5 \%$ dan $67,5 \%$.

Tingginya persentase serangan disebabkan oleh berbagai faktor, seperti panen tidak rutin, kondisi lahan, terutama keberadaan serasah dan kulit sisa panen. Menurut Sulistyowati et al. (2003), panen pada buah masak yang disertai dengan kegiatan sanitasi dapat menekan populasi hama PBK. Hal ini disebabkan pada buah masak awal, larva PBK masih di dalam buah, sehingga akan mati jika kulit buah dan plasenta langsung dibakar atau dibenamkan ke dalam tanah. Hal ini menunjukkan bahwa panen rutin dan pembersihan lahan dari kulit buah sisa panen dapat memutuskan siklus hidup PBK. Menurut Sulistyowati dan Wiryadiputra (2010), sisa daun bekas pangkasan dan kulit buah bekas panen dapat menjadi tempat PBK, sehingga populasi PBK pada kebun yang tidak disanitasi lebih tinggi dibandingkan dengan kebun yang dilakukan sanitasi.

Pada cabang tanaman yang terlindungi sinar matahari, aktivitas imago PBK tinggi. Hai ini disebabkan cabang yang mendapat intensitas cahaya rendah menjadi tempat istirahat imago PBK pada siang hari, sedangkan penyebarannya dibantu angin. Sulistyowati (2002), menyatakan pula bahwa pemangkasan paling sedikit dilakukan dua kali setahun, sehingga cahaya dapat 
menembus ke dalam pertanaman kakao dan sirkulasi udara dalam pertanaman kakao akan lebih baik. Kondisi pertanaman kakao yang demikian tidak sesuai untuk perkembangan populasi PBK.

Nainggolan (2001), menjelaskan bahwa fluktuasi kelembaban berperan besar dalam mengatur aktivitas organisme dan sering menjadi faktor pembatas terhadap dinamika populasi dan penyebaran serangga. Menurut Shi et al. (2011), suhu mempengaruhi fisiologi, kelimpahan, fenologi, distribusi serangga dan dimensi serangga. Hasil penelitian Thomson et al. (2010), menunjukkan bahwa perubahan suhu dapat mempengaruhi populasi dan distribusi serangga fitofag (Lepidoptera) yang merupakan ordo dari PBK.

Tabel 2 Agroekosistem kebun kakao di Kecamatan Sitiung.

\begin{tabular}{|c|c|c|c|c|}
\hline \multirow{2}{*}{ Kondisi lahan } & \multicolumn{4}{|c|}{ Lokasi penelitian } \\
\hline & Siguntur & Sitiung & Gunung medan & Sungai Duo \\
\hline Umur tanaman & \pm 20 tahun & \pm 20 tahun & \pm 15 tahun & \pm 20 tahun \\
\hline Jarak tanam & $3.5 \times 3 \mathrm{~m}$ & $3 \times 3 \mathrm{~m}$ & $2.5 \times 3.5 \mathrm{~m}$ & $3.5 \times 3.5$ \\
\hline $\begin{array}{l}\text { Sistem } \\
\text { pertanaman }\end{array}$ & $\begin{array}{l}\text { Polikultur } \\
\text { (duku,pinang, } \\
\text { jeruk) }\end{array}$ & $\begin{array}{l}\text { Polikultur } \\
\text { (pinang,duku, } \\
\text { durian) }\end{array}$ & $\begin{array}{l}\text { Polikultur } \\
\text { (merica,durian, } \\
\text { pepaya) }\end{array}$ & $\begin{array}{l}\text { Polikultur } \\
\text { (kelapa, } \\
\text { karet) }\end{array}$ \\
\hline Pemupukan & $\begin{array}{l}\text { Tidak dilakukan } \\
\text { pemupukan }\end{array}$ & $\begin{array}{l}\text { Tidak dilakukan } \\
\text { pemupukan }\end{array}$ & $\begin{array}{l}\text { Dilakukan } 2 \mathrm{x} \\
\text { setahun dengan } \\
\text { pupuk Urea, } \mathrm{KCl} \\
\text { dan NPK }\end{array}$ & $\begin{array}{l}\text { Pemupukan } \\
\text { dengan } \\
\text { pupuk } \\
\text { kandang sapi }\end{array}$ \\
\hline Panen & Tidak rutin & Rutin & Tidak rutin & Tidak rutin \\
\hline Sanitasi & Tidak dilakukan & Tidak dilakukan & Dilakukan & $\begin{array}{l}\text { Tidak } \\
\text { dilakukan }\end{array}$ \\
\hline Pemangkasan & Tidak dilakukan & Tidak dilakukan & $\begin{array}{l}\text { Dilakukan 1x4 } \\
\text { bulan }\end{array}$ & $\begin{array}{l}\text { Tidak } \\
\text { dilakukan }\end{array}$ \\
\hline
\end{tabular}

Dibandingkan dengan ketiga nagari lainnya, Gunung Medan paling sedikit mengalami serangan PBK (Gambar 2). Pertanaman kakao di nagari ini memiliki pengelolaan yang baik, yaitu kebersihan lahan terjaga, panen rutin setiap minggu, pemangkasan teratur setiap 4 bulan dan pengendalian organisme pengganggu tanaman berkala setiap bulan. Pemangkasan pada tanaman kakao ditujukan untuk menghasilkan kerangka arsitektur dasar (frame) percabangan yang baik. Selain itu, pemangkasan juga dilakukan untuk mengatur distribusi cabang dan ranting produktif pada tajuk, meningkatkan produktivitas tanaman dan mengurangi risiko serangan hama dan patogen.
Populasi hama PBK dipengaruhi pula oleh suhu. Menurut Jumar (2010), kisaran suhu untuk perkembangan serangga adalah $15^{-} 45^{\circ} \mathrm{C}$, dengan suhu optimum $25^{\circ} \mathrm{C}$. Selain itu populasi PBK akan menurun pada curah hujan tinggi, karena jumlah telur yang dapat disimpan terbatas, serangan larva PBK berkurang (Lim 1992).

Persentase serangan di Nagari Siguntur, Sitiung dan Sungai Duo mengalami peningkatan pada setiap waktu pengamatan. Kondisi demikian juga terlihat pada Nagari Gunung Medan yang mengalami peningkatan dari minggu ke-1 sampai minggu ke-4, dan tidak mengalami peningkatan pada minggu ke-5 (Gambar 2). 


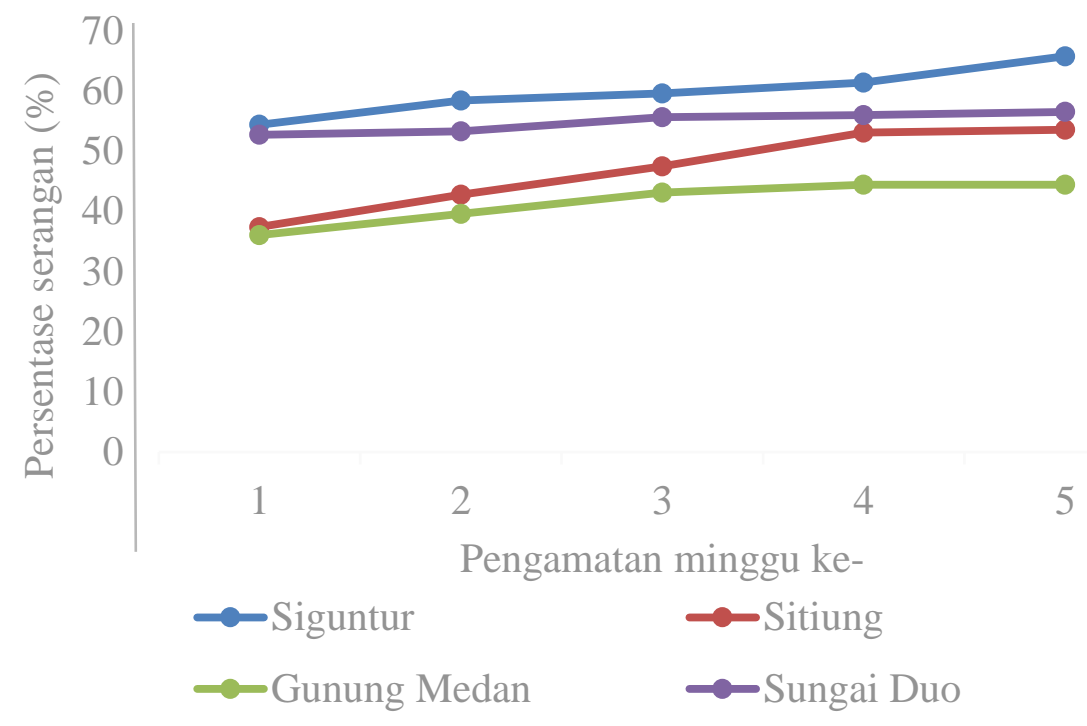

Gambar 2 Persentase tanaman terserang di Kecamatan Sitiung

\section{Persentase buah terserang}

Buah kakao yang paling banyak diserang PBK terdapat di Nagari Siguntur yakni $14,45 \%$ dan persentase terendah terdapat di Gunung Medan yakni $6.15 \%$ (Gambar 3).

Kerusakan buah kakao disebabkan oleh adanya larva penggerek buah kakao. Larva menyerang pulp dan plasenta, sehingga menyebabkan biji di dalam buah kakao saling melekat. Sulistyowati (1997), menyatakan bahwa buah kakao yang terserang PBK umumnya masak lebih awal, dengan warna kulit buah belang kuning hijau atau kuning jingga. Bobot buah kakao yang terserang meningkat dan bila diguncang tidak terdengar suara benturan antara biji dengan dinding buah.

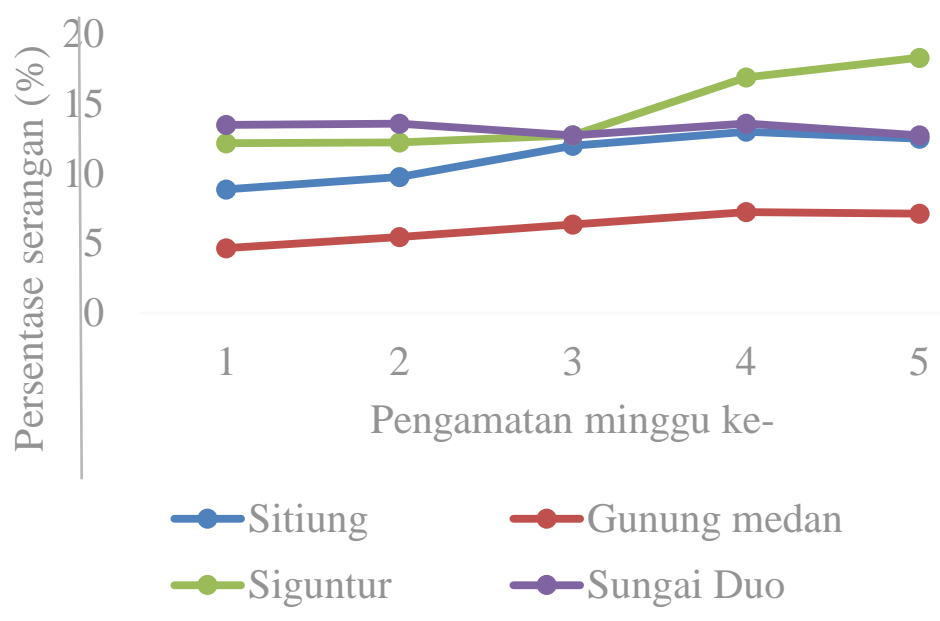

Gambar 3 Perbandingan buah terserang di Kecamatan Sitiung 
Perbedaan karakteristik permukaan kulit buah juga dilaporkan berpengaruh terhadap kesukaan peletakan telur serangga PBK. Azhar et al. (2000) dan Flood et al. (2004), menyebutkan bahwa buah-buah yang permukaan kulitnya kasar lebih disukai oleh serangga PBK untuk bertelur. Lim (1992), melaporkan bahwa telur PBK lebih banyak ditemukan di bagian alur buah (furrow) dibandingkan di bagian puncak buah (ridge). Kedalaman alur mencerminkan tingkat kekasaran permukaan kulit buah. Menurut Teh et al. (2006), telur PBK yang diletakkan pada permukaan buah yang kasar akan lebih terlindung dari curahan air hujan.
Fluktuasi serangan hama PBK pada setiap lahan disebabkan oleh berbagai faktor salah satunya ketersediaan buah di lapangan. Ketersediaan buah sebanyak $72 \%$ dapat menunjang satu generasi, $21 \%$ menunjang dua generasi dan $7 \%$ menunjang tiga generasi. Populasi hama PBK akan meningkat dengan berkurangnya jumlah buah yang tersedia di lapangan, sehingga terjadi serangan berat (Sulistyowati 2003).

\section{Letak buah terserang}

Buah kakao yang paling banyak terserang terdapat pada cabang sekunder, sedangkan serangan terendah pada batang (Tabel 3).

Tabel 3 Letak buah terserang di Kecamatan Sitiung

\begin{tabular}{lccc}
\hline \multirow{2}{*}{ Nagari } & \multicolumn{3}{c}{ Letak buah terserang $(\%)$} \\
\cline { 2 - 4 } & Batang & Cabang primer & Cabang sekunder \\
\hline Siguntur & 3,65 & 3,19 & 93,15 \\
Sitiung & 5,80 & 14,73 & 79,46 \\
Gunung Medan & 3,63 & 18,18 & 68,18 \\
Sungai Duo & 2,26 & 9,06 & 88,67 \\
\hline
\end{tabular}

Hal tersebut disebabkan karena tidak adanya pemangkasan yang dilakukan petani sehingga kelembaban tinggi, umumnya cabang sekunder pada ujung-ujung cabang terhalang daun sehingga senyawa yang dikeluarkan buah kakao tertangkap oleh imago betina PBK yang aktif pada malam hari untuk peletakan telur.

Salah satu tanda yang mempengaruhi orientasi serangga pada inangnya adalah senyawa kimia yang diemisikan ke udara oleh inangnya tersebut, serta tidak dilakukannya kegiatan pemangkasan, yang membuat tanaman rimbun dan kelembabannya tinggi yang menjadi tempat berkembangnya hama.

\section{Intensitas serangan}

Intensitas serangan tertinggi terdapat pada Nagari Siguntur yaitu $76 \%$ dan persentase terendah pada Nagari Gunung Medan yaitu $15.91 \%$ (Gambar 4). Hal iniberkaitan dengan tindakan kultur teknis berupa pemangkasan, sanitasi kebun, dan panen dilakukan secara rutin. Menurut Azhar (2000), tingkat serangan dan buah terserang PBK tinggi belum tentu diikuti oleh intensitas serangan yang tinggi pula. Intensitas serangan PBK pada buah kakao sangat ditentukan oleh tingkat kerusakan biji kakao. Fluktuasi banyaknya tanaman terserang dan buah terserang bergantung pada kegiatan pengendalian yang dilakukan petani. 


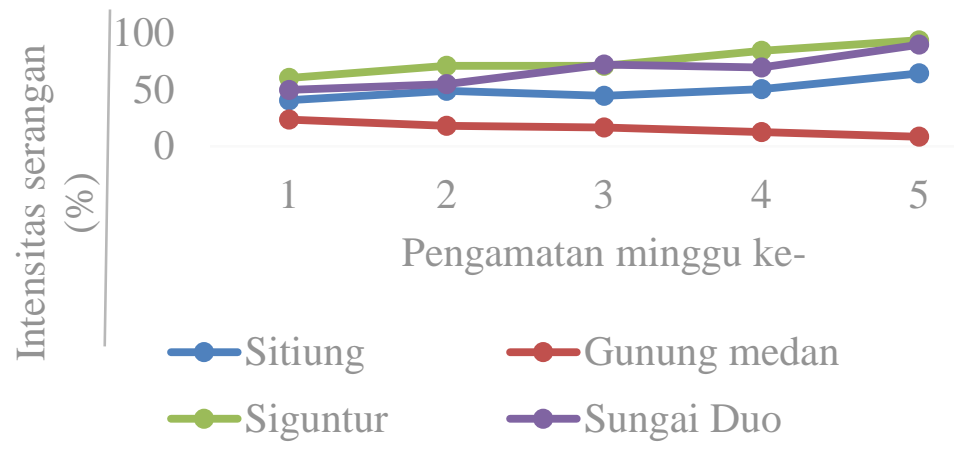

Gambar 4 Perbandingan intensitas serangan di Kecamatan Sitiung

\section{Kehilangan hasil}

Kehilangan hasil tertinggi terdapat di Siguntur dengan persentase kehilangan $7.61 \%$ dan persentase kehilangan terendah terdapat pada Nagari Gunung Medan, sebesar $1.57 \%$ (Tabel 7).

Kehilangan hasil panen paling tinggi terdapat di Nagari Siguntur. Kehilangan hasil ditentukan berdasarkan intensitas serangan. Serangan PBK menyebabkan penurunan bobot dan mutu produk (biji rusak, keriput, dan kulit biji berwarna gelap). Kerugian oleh PBK merupakan berasosiasi dengan penurunan bobot, kualitas produk dan peningkatan ongkos panen, akibat penambahan waktu dan tenaga kerja untuk memisahkan biji sehat dari biji yang terserang.

\section{KESIMPULAN}

Persentase serangan PBK tertinggi berada pada Nagari Siguntur dengan persentase tanaman terserang 59,93\%, persentase buah terserang $14,45 \%$, intensitas serangan $76 \%$ dan kehilangan hasil $7,61 \%$. Persentase serangan PBK terendah pada Nagari Gunung Medan dengan rata-rata persentase tanaman terserang $41,54 \%$ persentase buah terserang $6,15 \%$ intensitas serangan $15,91 \%$ dan kehilangan hasil $1,57 \%$. Buah terserang paling banyak terdapat pada cabang sekunder.

\section{DAFTAR PUSTAKA}

Azhar I. 2000. Measuring ovipositional preference of the cocoa pod borer, Conopomorpha cramerela (Lepidoptera: Gracillariidae) to various cocoa clones. Proceedings of Incoped 3rd International Seminar. Malaysian Cocoa Board. 57-59.

Badan Pusat Statistik Dharmasraya. 2015. Dharmasraya dalam Angka 2015. Dharmasraya.

Depparaba F. 2002. Penggerek buah kakao (Conopomorpha cramerella Snellen) dan penanggulangannya. Jurnal Litbang Pertanian. 21 (2):69-74.

Direktorat Jenderal Perkebunan. 2017. Statistik Perkebunan Indonesia Komoditas Kakao 2014-2016. Jakarta: Sekretariat Direktorat Jenderal Perkebunan.

Flood J, Guest D, Holmes KA, Keane P, Padi B, Sulistyowati E. 2004. Cocoa under attack. p. 33-53. In: J. Flood \& R. Murphy (Eds.). Cocoa Futures: A Source Book of Some Important Issues Confronting the Cocoa Industry. CABI Commodities, Colombia.

Karmawati E. 2010. Pengendalian hama Helopeltis spp. pada tanaman jambu mete berdasarkan ekologi, strategi dan implementasinya. Pengembangan Inovasi Pertanian. Jurnal Litbang Pertanian 3:102-119. 
Kiranta F, Meydianawathi LG. 2014. Analisis tingkat daya saing ekspor biji kakao indonesia tahun 2007-2012. EJurnal EP Unud. 3(11):502-512.

Lim GT. 1992. Biology, ecology, and control of cocoa pod borer Conopomorpha cramerella (Snellen). In Cocoa Pest and Disease Management in Southeast Asia and Australia. FAO Plant Prod. and Protection, 12, 85-100.

Nainggolan D. 2001. Aspek Ekologis Kultivar Buah Merah Panjang (Pandanus conoideus Lamk) di Daerah Dataran Rendah Manokwari. Manokwari:

Priyatno E. 2015. Hama dan Penyakit Tanaman Kakao (Theobroma cacao L.). Bantul.

Shi P, Zhong L, Sandhu HS, Ge F, Xu X, Chen W. 2011. Population decrease of Scirpophaga incertulas (Walker) (Lepidoptera Pyralidae) under climate warming. Ecologi and Evolution 2: 5864.

Siswanto, Karmawati E. 2012. Pengendalian hama utama kakao (Conopomorpha cramerella dan Helopeltis spp.) dengan pestisida nabati dan agens hayati. Jurnal Perspektif 11 (2):99-103.

Siska M. 2015. Tingkat Serangan Hama Penggerek Buah Kakao (Conomorpha cramerella Snell.) (Lepidoptera: Gracillaridae) di Kabupaten Agam. [Skripsi]. Fakultas Pertanian. Universitas Andalas. Padang.

Sulistyowati E. 1997. Prospek pemanfaatan tanaman tahan dalam pengelolaan hama penggerek buah kakao. Warta Pusat Penelitian Kopi dan Kakao 13 (3): 204-212.

Sulistyowati E, Sri S, Wiryadiputra S, Junianto Y.Dj., Saidi. 2002. Pengenalan dan Pengendalian Hama Penyakit Tanaman Kakao. Jember, Jawa Timur: Puslitkoka. 28 hal.
Sulistyowati E., Susilo AW, Prawoto A, Mufrihati E. 2004. Pengendalian terpaduhama penggerek buah kakao (PBK, Conopomorpha cramerella Snellen). hlm. 112-130. Prosiding Simposium Kakao, Yogyakarta, 45 Oktober 2004. Jember: Pusat Penelitian Kopi dan Kakao Indonesia.

Sulistyowati E, Wiryadiputra S. 2010. Hama Utama Kakao dan Pengendalian. Buku pintar Budidaya Kakao. Pusat Penelitian Kopi dan Kakao Indonesia. Jakarta: Agromedia Pustaka.

Sulistyowati E. 2003. Pengendalian hama utama, teknik pengamatan dan pengendaliannya pada tanaman kakao, teknik budidaya dan pengolahan.

Tan SG, Muhamad R, Gan YY, Rita M. 1988. Hexokinase, malate dehydro-genase, fluorescent esterase and malic enzyme polymorphisms in the cocoa pod borer, Conopomorpha cramerella (Snellen). Pertanika. 11:7-13.

Teh CL, Joe T-Y Pang, Ho C-T. (2006). Variation of the response of clonal cocoa to attack by cocoa pod borer Conopomorpha cramerella (Lepidoptera: Gracillariidae) in Sabah. Crop Protection, 25:712-717.

Thomson LJ, Macfadyen S, Hoffmann AA. 2010. Predicting the effects of climate change on natural enemies of agricultural pests. Biological Control 52:296-306.

Wardojo S. 1980. The cocoa podborer major hidranceto development. Indonesian Agricultural Research \& Development Journal. 2:1-4.

Wiryadiputra S, Sulistyowati E, Prawoto AA. 1994. Teknik pengendalian hama penggerek buah kakao Conopomorpha cramerella (Snellen). Lokakarya Penanggulangan Hama PBK di Indonesia. Jember, 8 Februari 1994. 
Yulita E. 2014. Tingkat serangan hama penggerek buah kakao (Theobroma cacao L.) di Kabupaten Pasaman Barat. [Skripsi].
Fakultas Pertanian. Universitas Andalas. Padang. 